ISPEC Tarım Bilimleri Dergisi

$2020: 4(3)$

(C) Telif hakk ISPEC'e aittir

Arastırma Makalesi

\section{*Ferit YILDIRIM}

Orcid No: 0000-0002-4753-850

**Nizamettin TURAN

Orcid No: 0000-0002-4026-6781

*Mardin İl Tarım ve Orman

Müdürlüğü, Midyat İlçe Müdürlüğü

**Siirt Üniversitesi Tarla Bitkileri

Bölümü (Sorumlu yazar)

nturan49@gmail.com

DOI

https://doi.org/10.46291/ISPECJASv ol4iss3pp477-491

Not: $\mathrm{Bu}$ çalışma, ilk yazarın yüksek lisans çalışması olup, özet kısmı 1. Uluslararası Çayır-Mera ve Yem Bitkileri kongresinde sunulmuştur.

Geliş Tarihi: 06/07/2020

Kabul Tarihi: 07/08/2020

\author{
Anahtar Kelimeler \\ Baklagil, kalite, tek yıllık, tür, yem \\ bitkisi, verim

\section{Keywords} \\ Forage crops, legume, annual, yield, \\ variety, quality
}

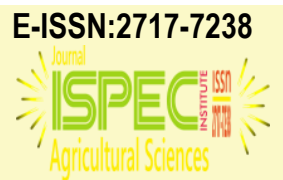

ISPEC Journal of Agr. Sciences

$2020: 4(3)$

Copyright (C) ISPEC

$\underline{\text { Research Article }}$

www.ispecjournal.com

Tek Yıllık Bazı Baklagil Yem Bitkilerinin Verim ve Verim Unsurları İle Bazı Silaj Özelliklerinin Belirlenmesi

\section{Özet}

Bu çalışma, bazı tek yıllık baklagil yem bitkilerinin Siirt ili kuru şartlarında verim ve verim unsurları ile bazı silaj özelliklerinin belirlenmesi amaciyla 2018-2019 yetiştirme döneminde yürütülmüştür. Çalışmada, bitkisel materyal olarak 10 farklı baklagil yem bitkisi türü kullanılmıştır. Bunlar; Gap Pembesi (Yem bezelyesi), Doruk (Yaygın fiğ), Görkem (Koca fiğ), Tarm beyazı (Macar fiği), Efes-79 (Tüylü fiğ), Derya (İskenderiye üçgülü), Göryaka (Yem baklas1), Gap mavisi (Mürdümük), Hat-8 (Burçak) ve Berkem (Çemen) türleridir. Tarla denemesi tesadüf blokları deneme desenine göre 3 tekerrürlü olarak kurulmuştur. Araştırmada; Bitki boyu $(\mathrm{cm})$, yeşil ot verimi $\left(\mathrm{kg} \mathrm{ha}^{-1}\right)$, kuru ot verimi $\left(\mathrm{kg} \mathrm{ha}^{-1}\right)$, kuru ot oranı, silaj $\mathrm{pH}$ değeri, laktik asit (LA) oranı, kuru madde tüketim (KMT) oran1, ham protein (HP) oran1, ham protein verimi $\left(\mathrm{kg} \mathrm{ha}^{-1}\right)$, ADF ve NDF oran1, sindirilebilir kuru madde (SKM) oranı, nispi yem değeri (NYD), silaj kuru madde (KM) oranı incelenmiştir. Araştırma sonucuna göre; Ortalama bitki boyu $66.17 \mathrm{~cm}$, yeşil ot verimi $29.530 \mathrm{~kg} \mathrm{ha}^{-1}$, kuru ot verimi $7.281 \mathrm{~kg} \mathrm{ha}^{-1}$, kuru ot oran $\% 24.39$, silaj $\mathrm{pH}$ değeri 4.40 , laktik asit oranı $\% 1.89$, kuru madde tüketimi $\% 3.36$, ham protein oran1 $\% 18.32$, ham protein verimi $132.97 \mathrm{~kg} \mathrm{ha}^{-1}$, ADF \%27.89, NDF \%35.81, SKM \%67.17, NYD 174.96, silaj kuru madde \%34.53 arasında değişim göstermiştir. Tüm sonuçlar göz önünde bulundurulduğunda, burçak ve fiğ türlerinin diğer türlere göre hem verim hem de kalite açısından daha üstün bulunmuştur.

\section{Determination of Yield And Yield Components And} Some Silage Properties Of Some Annual Legume Forage Crops

\section{Abstract}

This study was carried during the 2018-2019 cultivation period in order to determine yield and yield components and weed and silage quality of some annual legume forage plants in Siirt ecological conditions in the dry conditions of Siirt province. In this study, 10 different legume forage plant species were used as plant material. These are Gap Pembesi (Forage pea), Doruk (Common vetch), Görkem (Narbonne vetch), Tarm Beyazı (Hungarian vetch), Efes-79 (Hairy vetch), Derya (Berseem clover), Native ecotype (Feed beans), Gap Mavisi (Grasspea), Native ecotype (Bitter vetch), Berkem (Fenugreek). The field experiment was conducted in such a way as to have 3 repetitions according to the pattern of random blocks. In the study; plant height $(\mathrm{cm})$, green herbage yield $\left(\mathrm{kg} \mathrm{ha}^{-1}\right)$, hay yield $\left(\mathrm{kg} \mathrm{ha}^{-1}\right)$, hay yield ratio, silage $\mathrm{pH}$, Lactic acid (LA) ratio, Dry matter intake (DMI) ratio, Crude protein (CP) ratio, Crude protein (CP) yield $\left(\mathrm{kg} \mathrm{ha}^{-1}\right)$, Acid detergent fiber (ADF) and Neutral detergent fiber (NDF) ratios, Digestible dry matter (DDM) ratio, Relative feed value (RFV) examined the properties of silage Dry matter (DM). According to the research results; $66.17 \mathrm{~cm}$ average plant height, green herbage yield $29.530 \mathrm{~kg}$ $\mathrm{ha}^{-1}$, hay yield $7.281 \mathrm{~kg} \mathrm{ha}^{-1}$, hay matter ratio $24.39 \%$, the value of silage $\mathrm{pH} 4.40$, LA of $1.89 \%$, DMI $3.36 \%$, CP $18.32 \%$, CP yield 1.330 $\mathrm{kg} \mathrm{ha}^{-1}$, ADF ratio $27.89 \%$, NDF ratio $35.81 \%$, DDM $67.17 \%$, the value of RFV 174.96 and silage DM ratio 34.53. Considering all the results, bitter vetch and vetch varieties were found to be superior in both yield and quality compared to other varieties. 


\section{GíRIŞ}

Baklagillerin kış dönemi için kuru ot veya otlak sistemleri içerisinde yetiştiricilikleri yaygın olup eskilere dayanır. Fakat bu gruba giren bitkilerin son yıllarda silaj olarak saklanıp değerlendirilmeleri yaygınlaşmaya başlamıştır. ABD'de süt inekçiliğinin yoğun olarak yapıldığı eyaletlerde mısırdan sonra en fazla silaja katılan bitki yoncadır. Amerika'nın Wisconsin eyaletinde yoncanın \%50'den fazlası silaj olarak değerlendirilmektedir (Anonim, 2001). Ülkemizde çiftlik hayvanı varlığına göre kaba yem üretimi oldukça yetersiz durumda olup kaliteli olarak niteleyebileceğimiz kuru ot üretimimiz 4 milyon ton dolaylarındadır (Yolcu ve Tan, 2008). Silaj üretimi de hesaba katıldığında ülkemizde ihtiyaç olan kaba yem talebinin ancak \%3035'i karşılanmaktadır (Anonim, 2015). Kaba yem açığımızın azaltılmasında ya da kapatılmasında ara ürün olarak tek yıllık baklagil yem bitkilerinin kuru ot veya silaj amaciyla yetiştirilmesi faydalı olabilmektedir. Baklagillerin silaj yapılarak hayvanlara yedirme çabaları konusundaki ilk girişimler sıklıkla başarısız olmuş ve sağlıklı yem üretilmemiştir. $\mathrm{Bu}$ nedenle önceleri baklagillerin sağliklı fermantasyonunun olmayacağı düşüncesi yaygın olsa da son 20 yıldır yapılan yoğun çalışmalar bu konudaki sorunları büyük oranda çözüme kavuşturmuştur. Kuru ot yapımı yağış rejimi nedeniyle zor olan yerlerde yemin muhafazası için silaj yapımı yaygınlaşmaktadır. Gelişen silaj yapım teknolojisi ile birlikte günümüzde yemlik baklagillerin hayvanlar üzerinde herhangi bir olumsuz etkisi olmaksızın silaj formunda kullanılabileceği ortaya çıkmıştır. Yaz yağışlarının sık olduğu bölgelerde çok yıllık baklagillerin silaj yapılması için hasat edilmesi kuru ot yapımından daha kolaydır. Örneğin Doğu Anadolu'da yoncanın birinci biçimi bahar yağmurlarının yoğun olduğu mayıs ayı sonuna denk gelmektedir. $\mathrm{Bu}$ nedenle kurutulmak üzere yapilan biçimlerde genellikle başarılı sonuçlar alınmamaktadır. Kurumakta olan yonca ve üçgül üzerine yağmur yağarsa \%14-43 kuru madde kaybı meydana gelmektedir. $\mathrm{Bu}$ durum otun sindirilmesinde \%27'lik bir azalmaya yol açmaktadır (Collins, 1983). Otun tarlada daha kısa süre kalması, mekanizasyon ve işgücü ihtiyacının azalmasından dolayı son 20 yıllık süre zarfinda kuzey ABD ve Kanada' da baklagil silajı üretimi belirgin biçimde artış göstermiştir (Albrecht ve Beauchemin, 2003). Konu ile ilgili olarak; Kökten ve ark. (2018) Bingöl koşullarında burçak 
genotiplerinde ortalama bitki boyu $31.6 \mathrm{~cm}$, yeşil ot verimi $412.5 \mathrm{~kg} / \mathrm{da}$, kuru ot verimi $95.6 \mathrm{~kg} / \mathrm{da}$, ham protein oranı 13.8 olarak belirlenmişlerdir. Kökten ve ark. (2019) Bingöl ekolojik koşullarında bazı burçak genotiplerinin ortalama ADF oranını \%37.6, NDF oranın 1 ise $\% 47.4$ olarak tespit ettiklerini rapor etmişlerdir. Alp (2019) Şanlıurfa ekolojik koşullarında çemen (Trigonella foenum-graecum L.) bitkisinde farklı ekim zamanlarının ot verimi ve bazı kalite özelliklerinin incelenmesi ile ilgili 2017-2018 yıllarında yürüttüğü araştırmada; bitki boyu 20.47-38.63 cm, yeşil ot verimi $60.04-2156.50 \mathrm{~kg} / \mathrm{da}$, kuru ot verimi $12.77-430.67 \mathrm{~kg} / \mathrm{da}$, ham protein oranı ise \%13.87-20.95 arasında varyasyon gösterdiğini ifade etmektedir. Ayrıca; Ankara şartlarında burçak hatları ile 2 yıl süre ile yürütülen araştırmada bitki boyunun 33.27-47.53 cm ve biyolojik verimin $237.15-457.68 \mathrm{~kg} / \mathrm{da}$ arasında değiştiğini ifade eden bazı araştırıcıların (Kendir, 1999)'in yanı sıra; aynı ekolojik şartlarda 7 çemen hattı ile yürütülen çalışmada bitki boyunun $49.40-71.40 \mathrm{~cm}$ ve biyolojik verimin 399.3-741.8 $\mathrm{kg} / \mathrm{da}$ arasında değişim gösterdiği başka araştırıcılar tarafından (Özdemir ve Gürbüz, 1998) ifade edilmektedir. Siirt şartlarında 2016-2017 y1llarında Turan ve Sakman
(2019) tarafından yazlık olarak yetiştirilen bazı koca fiğ (Vicia narbonensis L.) çeşitlerinin doğal bitki boylarının 62.8-85.0 $\mathrm{cm}$, kuru ot verimlerinin $272.3-382.0 \mathrm{~kg} / \mathrm{da}$, ham protein oranlarının \%20.3-21.4, ham protein verimlerinin $55.6-81.3 \mathrm{~kg} / \mathrm{da}, \mathrm{ADF}$ oranlarının \%29.3-33.1, NDF oranlarının \%38.6-44.8 ve nispi yem değerlerinin 149.6-182.8 arasında değiştiği; Siirt ekolojik şartlarına benzerlik gösteren Diyarbakır şartlarında 8 farklı burçak genotipi ile yapılan bir araştırmada (Seydoşoğlu ve ark., 2015) bitki boyunun 28.6-39.5 cm, yeşil ot verimi 1613.5-2039.5 $\mathrm{kg} / \mathrm{da}$, kuru ot verimi 422.6-509.3 kg/da arasında değiştiği ifade edilmektedir. Bu çalışmada; bölgede hayvansal varlığın sürdürülebilmesi, yüksek ve kaliteli hayvansal ürünlerin elde edilebilmesi, çayır ve meralar üzerindeki baskıların azaltılması ve üretimi yetersiz olan kaliteli kaba yemin artırılmasına katkı sağlamak için tek yıllık bazı baklagil yem bitkileri türlerinin verim ve verim unsurları ile bazı silaj özellikleri belirlenerek tarımsal özellikler yönünden adaptasyon kabiliyeti yüksek olan tür ya da türlerin ortaya konulması amaçlanmıştır.

\section{MATERYAL ve YÖNTEM}

$\mathrm{Bu}$ araştırma; Siirt şartlarında tek yıllık bazı baklagil yem bitkilerinin verim ve verim unsurları ile bazı silaj özelliklerinin 
belirlenmesi amacıyla kıș sezonunda yürütülmüştür. Araştırma ile ilgili tarla denemeleri, Siirt Üniversitesi Ziraat Fakültesi Uygulama arazisinde tesadüf blokları deneme desenine göre üç tekrarlamalı olarak tesis edilmiştir. Denemenin yürütüldüğü tarla arazisi sonbaharda pullukla derin sürülmüştür.
Ekim öncesi ikileme yapılarak ekime hazır hale getirilmiştir. Ekim, 25 cm'ye ayarlanan el markörü yardımıyla çizilen çizilere elle gerçekleştirilmiştir. Araştırmada, tarla denemesi kurulmadan önce 0-20 cm derinlikten alınan ve analizi yapılan toprakların bazı fiziksel ve kimyasal özellikleri Çizelge 1'de verilmiştir.

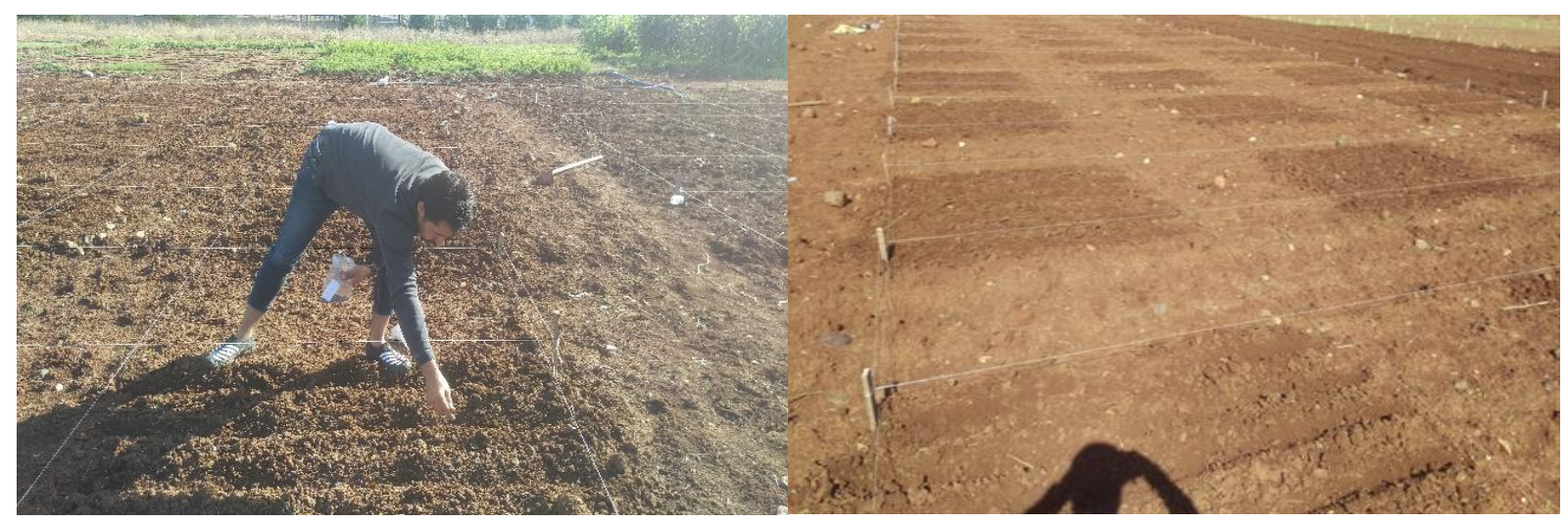

Resim 1. Tohum yatağının hazırlanması ve ekim işlemi

Çizelge 1. Araştırma yeri topraklarının bazı fiziksel ve kimyasal özellikleri $(0-20 \mathrm{~cm})^{*}$

\begin{tabular}{llr}
\hline Toprak özelliği & Birim & Değeri \\
\hline Kum & $\%$ & 14.00 \\
Kil & $\%$ & 58.00 \\
Silt & $\%$ & 28.00 \\
pH & & 7.95 \\
Elektriksel iletkenlik (EC) & $\mu \mathrm{S} / \mathrm{cm}$ & 107.00 \\
Kireç & $\%$ & 10.50 \\
Organik madde & $\%$ & 1.35 \\
Alınabilir fosfor (P) & $\mathrm{P}_{2} \mathrm{O}_{5} \mathrm{~kg} / \mathrm{da}$ & 2.30 \\
Alınabilir potasyum (K) & $\mathrm{ppm}$ & 652.00 \\
\hline${ }^{*}$ : Analizler, Siirt Üniversitesi, Bilim ve Teknoloji Uygulama ve Araştırma Merkezi Laboratuvarı'nda yapılmıştır
\end{tabular}

Çizelge 1 incelendiğinde; araştırma yeri topraklarının killi bünyeli, tuzsuz, hafif alkali ve orta kireçli olduğu, toprakların organik madde içeriklerinin az, bitkiler tarafindan alınabilir fosfor kapsamının çok az, alınabilir potasyum bakımından ise çok yüksek seviyede olduğu belirlenmiştir. Araştırmanın yürütüldüğ̈̈ iklim verileri incelendiğinde; 2019 y1lında toplam 626 mm yağış görülürken, 2018 yılında toplam $758.4 \mathrm{~mm}$ ve uzun y1llarda ise $638.3 \mathrm{~mm}$ yağış düştüğü kaydedilmiştir (Çizelge 2). 
Çizelge 2. Araştırma yerinin bazı iklim özellikleri (Anonim, 2019)

\begin{tabular}{|c|c|c|c|c|c|c|c|c|c|}
\hline \multirow[t]{2}{*}{ Aylar } & \multicolumn{3}{|c|}{ Sicaklık ( $\left.{ }^{\circ} \mathrm{C}\right)$} & \multicolumn{3}{|c|}{ Yağış (mm) } & \multicolumn{3}{|c|}{ Nispi nem (\%) } \\
\hline & UYO & 2018 & 2019 & UYO & 2018 & 2019 & UYO & 2018 & 2019 \\
\hline Ocak & 4.4 & 6.2 & 4.2 & 80.7 & 56.4 & 96.2 & 72.7 & 70.5 & 72.5 \\
\hline Şubat & 6.8 & 8.4 & 7.1 & 75.7 & 74.2 & 103.2 & 66.2 & 67.7 & 67.0 \\
\hline Mart & 10.7 & 15.3 & 9.1 & 100.3 & 47.6 & 185.2 & 60.0 & 55.9 & 67.4 \\
\hline Nisan & 15.4 & 16.7 & 12.8 & 98.5 & 61.6 & 175.8 & 55.0 & 47.6 & 66.8 \\
\hline Mayıs & 20.9 & 21.3 & 20.8 & 67.2 & 139.6 & 64.4 & 48.8 & 59.2 & 42.1 \\
\hline Haziran & 27.0 & 28.4 & 30.3 & 9.2 & 10.0 & 1.2 & 28.5 & 31.7 & 26.9 \\
\hline Temmuz & 31.2 & 32.4 & 31.4 & 1.2 & 0.6 & 0.0 & 20.7 & 20.1 & 23.7 \\
\hline Ağustos & 31.4 & 32.0 & - & 1.2 & 1.6 & - & 19.8 & 21.4 & - \\
\hline Eylül & 26.7 & 29.2 & - & 6.7 & 0.0 & - & 25.0 & 23.0 & - \\
\hline Ekim & 20.2 & 19.5 & - & 59.6 & 100.6 & - & 44.7 & 47.8 & - \\
\hline Kasım & 12.2 & 14.7 & - & 56.9 & 88.6 & - & 59.7 & 76.2 & - \\
\hline Aralık & 6.6 & 6.4 & - & 81.1 & 177.6 & - & 71.3 & 82.0 & - \\
\hline Ort./Top. & 17.8 & 19.2 & 16.5 & 638.3 & 758.4 & 626.0 & 47.7 & 50.2 & 52.3 \\
\hline
\end{tabular}

*: Siirt Meteoroloji İl Müdürlüğü, ${ }^{* *}$ : UYO: Uzun yıllar ortalaması (2010-2019)

\section{Verilerin Değerlendirilmesi}

Silajın ADF ve NDF oranları, Ondokuz Mayıs Üniversitesi Ziraat Fakültesi Tarla Bitkileri Bölümü Laboratuvarı'nda, NIRS (Near Infrared Reflektance Spectroscopy) analiz cihazı ile NIR (Near Infrared Analysis, Yakın Kızıl Ötesi Analizi) spektroskopik teknikle (Hoy ve ark., 2002) belirlenmiştir. Kaba yemin hayvan tarafindan tüketim potansiyeli ile sağlayacağı enerji değerinin tahminine yönelik bir indeks olan NYD, Van Dyke ve Anderson (2000) tarafından geliştirilen aşağıdaki eşitlikler yardımıyla belirlenmiştir. Bunun için öncelikle; Eşitlik 1 yardımıyla, sindirilebilir kuru madde (SKM \%); Eşitlik 2 ile kuru madde tüketimi (KMT \%) hesaplanmış; Eşitlik 3 yardımıyla da NYD saptanmıştır.

$$
\begin{aligned}
& \operatorname{SKM}(\%)=88.9-(0.779 \times \% \text { ADF })(1) \\
& \operatorname{KMT}(\%)=120 / \% \operatorname{NDF}(2) \\
& \operatorname{NYD}(\%)=\% \text { SKM x } \% \text { KMT x } 0.775
\end{aligned}
$$

Tek y1llık baklagil yem bitkileri türlerinin kuru otunda belirlenen HP, ADF, NDF ve NYD verilerinin kalite derecesinin değerlendirilmesinde Rohweder ve ark. (1978) tarafindan bildirilen Çizelge 4'teki değerlerden yararlanılmıştır. 
Çizelge 3. Baklagil, buğdaygil ve baklagil karışımlarına ait kalite standartları (Rohweder et al., 1978)

\begin{tabular}{ccccccc}
\hline Kalite & HP & ADF & NDF & \multirow{2}{*}{ SKM \% } & KMT & \% of BW \\
\cline { 2 - 4 } Stand. & & $\%$ of KM & & & NYD \\
\hline Prime & $>19$ & $<<31$ & $<<40$ & $>65$ & $>3.0$ & $>151$ \\
1 & $17-19$ & $31-35$ & $40-46$ & $62-65$ & $3.0-2.6$ & $151-125$ \\
2 & $14-16$ & $36-40$ & $47-53$ & $58-61$ & $2.5-2.3$ & $124-103$ \\
3 & $11-13$ & $41-42$ & $54-60$ & $56-57$ & $2.2-2.0$ & $102-87$ \\
4 & $8-10$ & $43-45$ & $61-65$ & $53-55$ & $1.9-1.8$ & $86-75$ \\
5 & $<<8$ & $>45$ & $>65$ & $<<53$ & $<<1.8$ & $<<75$ \\
\hline
\end{tabular}

Silaj pH değeri; parselden alınan numuneler ile yapılan silajlardan alınan $10 \mathrm{~g}$ örneğe 90 ml su ilave edilip iyice karıștırılıp pH metre ile ölçülmüştür.

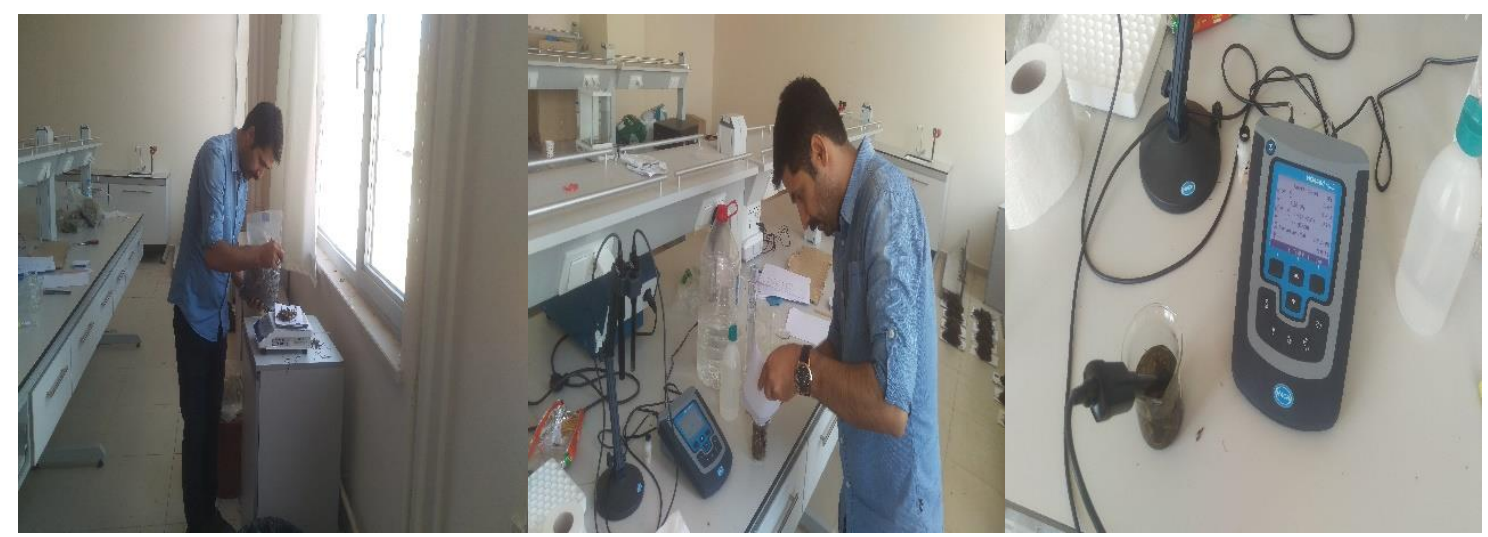

Resim 2. Silaj pH değerlerinin ölçülmesi

\section{Laktik Asit Orant}

Derin dondurucuda $-20{ }^{\circ} \mathrm{C}$ 'de saklanan örnekler analizin yapılacağı gün çıkartılarak çözülünceye kadar oda sıcaklığında bir süre bekletilmişlerdir. Çözündürülen örnekler daha sonra 1:100 oranında seyreltilerek kullanılmıştır. Seyreltilen örneklerden otomatik pipet yardımıyla $1 \mathrm{ml}$ sıvı tüplere aktarılmış ve üzerine $0.1 \mathrm{ml}$ bakır sülfat ( 5 g CuSO4/100 ml saf su) ile $6 \mathrm{ml} \mathrm{\% 98'lik}$ sülfürik asit ilave edilmiştir. Hazırlanan tüpler 30 sn vortekste karıştırıldıktan sonra $5 \mathrm{dk}$ soğuk banyoda tutularak soğumaya bırakılmıştır. $\mathrm{Bu}$ süre sonunda tüplere 0.1 $\mathrm{ml}$ para hidroxy bi phenol (\%0.5 Na $\mathrm{OH} / 1000 \quad \mathrm{ml} \quad$ saf $\quad \mathrm{su} \quad+2.5 \quad \mathrm{~g} \quad$ PHBP) eklenerek, tüpler 30 sn tekrar vortekste karıştırılmış ve $10 \mathrm{dk}$ oda sıcaklığında bekletilmiştir. Daha sonra tüpler 90 sn kaynar su içerisine daldırılıp çıkartılmış ve soğuması beklendikten sonra $565 \mathrm{~nm}$ dalga boyunda spektrofotometre cihazında okunmuştur (Taştan, 2016). Elde edilen veriler JMP (JMP $\AA$, Version 21 SAS Institute Inc., Cary, NC, 1989-2019) uygun istatistik paket programlarında 
değerlendirilip, ortalamalar arasındaki farkların önem düzeylerinin belirlenmesinde Duncan testinden yararlanılmıştır (Açıkgöz, 2001).

BULGULAR ve TARTIŞMA

Bitki Boyu, Yeşil Ot ve Kuru Ot Verimi, Silaj ADF Oranı
İncelenen tek y1llık bazı baklagil yem bitkilerinin bitki boyu değerleri bakımından türler arasındaki farklılık istatistiki açıdan önemli değilken, yeşil ot ve kuru ot verimi bakımından $\mathrm{p}<0.05$, ADF oranı bakımından ise $\mathrm{p}<0.01$ düzeyinde önemli bulunmuştur (Çizelge 4).

Çizelge 4. İncelenen özelliklere ait ortalama değerler

\begin{tabular}{lcccc}
\hline Türler & $\begin{array}{c}\text { Bitki boyu } \\
(\mathbf{c m})\end{array}$ & $\begin{array}{c}\text { Yeşil ot verimi } \\
(\mathbf{k g} / \mathbf{d a})\end{array}$ & $\begin{array}{c}\text { Kuru ot verimi } \\
(\mathbf{k g} / \mathbf{d a})\end{array}$ & ADF(\%) \\
\hline Koca fiğ (Görkem) & 69.67 & $2644.41 \mathrm{~b}-\mathrm{d}$ & $621.86 \mathrm{~b}-\mathrm{d}$ & $27.50 \mathrm{~cd}$ \\
Yem bezelyesi (Gap pembesi) & 69.00 & $2283.51 \mathrm{~cd}$ & $580.02 \mathrm{~cd}$ & $28.20 \mathrm{bc}$ \\
Çemen (Berkem) & 68.33 & $3566.13 \mathrm{ab}$ & $976.58 \mathrm{ab}$ & $28.10 \mathrm{bc}$ \\
Yem baklasi (Göryaka) & 68.00 & $1605.44 \mathrm{~d}$ & $319.13 \mathrm{~d}$ & $24.41 \mathrm{e}$ \\
İskenderiye üçgülü (Derya) & 67.67 & $3939.18 \mathrm{a}$ & $889.48 \mathrm{a}-\mathrm{c}$ & $28.82 \mathrm{a}-\mathrm{c}$ \\
Burçak (Hat-8) & 67.00 & $3911.21 \mathrm{a}$ & $989.10 \mathrm{a}$ & $28.53 \mathrm{a}-\mathrm{c}$ \\
Mürdümük (Gap mavisi) & 66.67 & $2916.33 \mathrm{a}-\mathrm{c}$ & $739.72 \mathrm{a}-\mathrm{c}$ & $28.00 \mathrm{bc}$ \\
Macar fĭ̆ (Tarm beyaz1) & 66.00 & $3331.25 \mathrm{a}-\mathrm{c}$ & $843.99 \mathrm{a}-\mathrm{c}$ & $29.34 \mathrm{ab}$ \\
Tüylü fĭğ (Efes 79) & 62.67 & $2754.51 \mathrm{a}-\mathrm{d}$ & $693.58 \mathrm{a}-\mathrm{c}$ & $29.66 \mathrm{a}$ \\
Yaygin fĭg (Doruk) & 56.67 & $2583.17 \mathrm{~b}-\mathrm{d}$ & $627.23 \mathrm{~b}-\mathrm{d}$ & $26.35 \mathrm{~d}$ \\
\hline Ortalama & 66.17 & 2953.51 & 728.07 & 27.89 \\
\hline LSD & Ö.D & $2.470^{*}$ & $758.81 *$ & $2.98^{* *}$ \\
\hline OSD & Or. & &
\end{tabular}

*:Ortalamalar arasındaki fark $(\mathrm{p}<0.05)$ düzeyinde önemli, ${ }^{* *}$ : Ortalamalar arasındaki fark $(\mathrm{p}<0.01)$ düzeyinde önemli

Çizelge 4 incelendiğinde, yeşil ot verimi bakımından iskenderiye üçgülü, burçak, çemen, macar fiği, mürdümük ve tüylü fiğ türleri arasında istatistiki açıdan fark olmayıp, sayısal olarak değerlendirildiğinde en yüksek yeşil ot verimi iskenderiye üçgülünden $(3939.18 \mathrm{~kg} / \mathrm{da})$, en düşük ise yem baklasından $(1605.44 \mathrm{~kg} / \mathrm{da})$ alındığ 1 görülmektedir. Türlerin yeşil ot verimi ortalamas1 ise $2953.00 \mathrm{~kg} / \mathrm{da}$ olarak saptanmıştır. Yeşil ot veriminde olduğu gibi kuru ot veriminde de bazı türler (burçak, mürdümük, tüylü fiğ, çemen, iskenderiye üçgülü ve macar fiği) arasında istatistiki açıdan herhangi bir fark görülmemektedir. Ancak veriler sayısal olarak değerlendirildiğinde türlerin kuru ot verimleri $319.13-989.10 \mathrm{~kg} / \mathrm{da}$ arasında varyasyon göstermiş ve en yüksek kuru ot verimi burçakta $(989.10 \mathrm{~kg} / \mathrm{da})$, en düşük ise yem baklasinda $(319.13 \mathrm{~kg} / \mathrm{da})$ belirlenmiştir. Türlerin ortalama kuru ot verimi ortalamas ise $728.07 \mathrm{~kg} / \mathrm{da}$ olarak gerçekleşmiştir (Çizelge 4). Çizelge 4'te görüldüğü gibi $\mathrm{ADF}$ oranı bakımından türler arasındaki farkl11lk istatistiki açıdan 
\%1 düzeyinde önemli bulunurken; Tüylü fiğg, macar fiği, iskenderiye üçgülü ve burçak türleri arasında istatistiksel olarak herhangi bir fark gözlemlenmemiştir. $\mathrm{Bu}$ verilere göre en düşük $\mathrm{ADF}$ oranı yem baklasindan (\%24.41) elde edilirken, en yüksek tüylü fiğden (\%29.66) sağlanmıştır. Türlerin ADF oranı ortalaması ise \%27.89 olarak saptanmıştır. Çalışmada yeşil ot verimi, kuru ot verimi ve ADF oranı ile ilgili elde edilen bulgular; Bakoğlu ve ark. (2004) Bingöl, Özdemir ve Gürbüz (1998) ile Kendir (1999)'in Ankara, Kökten ve ark. (2011)'nın Elazı̆ğ, Seydoşoğlu ve ark. (2013) ile Seydoşoğlu ve ark. (2015)'nın Diyarbakır, Alp (2019)'ın Şanlıurfa, Akbay ve Erol (2020)'un Kahramanmaraş, Turan ve Sakman (2019)'ın Siirt, Kara (2015)'nın Aydın, Yücel ve ark. (2017)'nın Çukurova şartlarında tek yıllık bazı baklagil yem bitkilerinin tür, çeşit ve hatlarıyla yaptıkları çalışmalarda elde ettikleri bulgularla farklı veya uyumlu olduğu saptanmıştır. Kuru ot verimi, yeşil ot verimi ve ADF oranı ile ilgili elde edilen değerler ile literatür bulguları arasında görülen farklılıklar, bitkilerin ekolojik koşullara gösterdikleri reaksiyondan ve genetik yapılarından kaynaklanmış olabileceği, bununla birlikte toprak özelliklerinden, bakım ve uygulamalardan da etkilendiği düşünülmektedir. Nitekim Kendir (1999), baklagillerde dal sayısının genotipin yanında iklim ve çevre koşullarından da etkilendiğini bildirmektedir. Ayrıca Stoilova and Pereira (1999), bitki boyu kalıtsal bir özellik ise de çevresel faktörler bu karakter üzerinde etkili olduğunu ifade eden araştırıcının yanı sıra; Bernadette ve ark. (2000), çeşit içerisinde kalite özellikleri, kuru madde verimi ve morfolojik özellikler bakımından geniş bir genetik varyasyon olduğu; Karslı ve ark. (2005) ise NDF, ADF ve ADL içeriklerinde meydana gelen değişimlerin bitkisel materyallerdeki genotipik farklılıklardan ileri geldiğini ifade etmektedirler. Ayrıca türlerin ortalama ADF (\%27.89) oranları Rohweder et al., (1978)'nın baklagil, buğdaygil ve baklagil karışımlarına ait kalite standartlarına göre değerlendirildiğinde (Çizelge 4) en üstün kaliteli sınıfında yem elde edildiği görülmektedir. $\mathrm{Bu}$ da; tek yıllık baklagil yem bitkileri türlerinden elde edilen silajın sindirilme derecesinin yüksek olduğunu göstermektedir. Çünkü kaba yemlerin sindirilebilirliğinin iyi olması için ADF oranının düşük olması gerekir. Bu konu ile ilgili Kjos (1990)'un, düşük NDF yüksek yem alımıyla ilgili ve düşük ADF de yüksek sindirilebilirlikle ilişkili olduğunu ifade 
etmesi, çalışmanın sonuçlarını desteklemektedir.

\section{Silaj NDF, SKM, KMT Orant ve NYD}

Tek yıllık bazı baklagil yem bitkileri türleriyle yürütülen araştırmada silajın nötral deterjanda çözünmeyen lif (NDF) ve kuru madde tüketim (KMT) oranı bakımından türler arasındaki farklılık istatistiki açıdan önemsiz bulunurken, sindirilebilir kuru madde (SKM) ve nispi yem değeri (NYD) bakımından türler arasındaki farklılık istatistiki olarak $\mathrm{p}<0.01$ düzeyinde önemli bulunmuştur. Türlerin sindirilebilir kuru madde (SKM) tüketim oranlar1 ortalaması $\% 65.79-69.88$ arasinda değişim gösterirken, nispi yem değeri (NYD) 163.12-193.10 arasında değişmiştir. En yüksek SKM yem baklasında (\%69.88), en yüksek NYD ise aralarında istatistiki farklılık olmayan yem baklasında (193.10), yaygın fiğde (184.38) ve koca fiğde (181.44) tespit edilmiştir (Çizelge 5).

Çizelge 5. İncelenen özelliklere ait ortalama değerler

\begin{tabular}{lcccc}
\hline Türler & NDF(\%) & SKM (\%) & KMT (\%) & NYD \\
\hline Koca fĭ̆ (Görkem) & 34.67 & $67.47 \mathrm{bc}$ & 3.47 & $181.44 \mathrm{a}-\mathrm{c}$ \\
Yem bezelyesi (Gap pembesi) & 36.16 & $66.93 \mathrm{~cd}$ & 3.32 & $172.26 \mathrm{~b}-\mathrm{d}$ \\
Çemen (Berkem) & 36.64 & $67.01 \mathrm{~cd}$ & 3.28 & $170.36 \mathrm{~b}-\mathrm{d}$ \\
Yem baklas1 (Göryaka) & 33.73 & $69.88 \mathrm{a}$ & 3.56 & $193.10 \mathrm{a}$ \\
İskenderiye üçgülü (Derya) & 36.40 & $66.45 \mathrm{c}-\mathrm{e}$ & 3.30 & $170.09 \mathrm{~cd}$ \\
Burçak (Hat-8) & 36.72 & $66.67 \mathrm{c}-\mathrm{e}$ & 3.27 & $168.90 \mathrm{~cd}$ \\
Mürdümük (Gap mavisi) & 35.66 & $67.09 \mathrm{~cd}$ & 3.38 & $175.89 \mathrm{~b}-\mathrm{d}$ \\
Macar fiğ (Tarm beyazı) & 36.13 & $66.04 \mathrm{de}$ & 3.32 & $170.09 \mathrm{~b}-\mathrm{d}$ \\
Tüylü fĭ̆ (Efes 79) & 37.52 & $65.79 \mathrm{e}$ & 3.20 & $163.12 \mathrm{~d}$ \\
Yaygin fĭğ (Doruk) & 34.50 & $68.37 \mathrm{~b}$ & 3.48 & $184.38 \mathrm{ab}$ \\
\hline Ortalama & 35.81 & 67.17 & 3.36 & 174.96 \\
\hline LSD & Ö.D & $2.33^{* *}$ & Ö.D & $29.98^{* *}$ \\
\hline
\end{tabular}

**: Ortalamalar arasındaki fark $(\mathrm{p}<0.01)$

Baklagil yem bitkileri türlerinin sindirilebilir kuru madde tüketim (SKM) oranı ile ilgili elde edilen bulgular; Kara (2015)'in bulgularından daha yüksek iken; Seydoşoğlu (2019)'nun bulgularıyla uyumlu olduğu saptanmıştır. Nispi yem değeri (NYD) ise; Kökten ve ark. (2013), Kara (2015), Yücel ve ark. (2017) ve Seydoşoğlu (2019)'nun bulgularından daha yüksek; Turan ve Sakman (2019)'in bulgularıyla uyumlu olduğu belirlenmiştir. Türler arasında istatistiki açıdan $\mathrm{p}<0.01$ düzeyinde önemli bulunan ortalama SKM (\%67.17) oranı ve Nispi Yem Değeri (NYD) (174.96) incelendiğinde (Çizelge 5); baklagil, buğdaygil ve baklagil karışımlarına ait kalite standartlarına (Rohweder et al., 1978) göre en üstün kaliteli sınıfında yem elde edildiği görülmektedir (Çizelge 3). Bu da; tek yıllık 
baklagil yem bitkileri türlerinden elde edilen silajın sindirilme derecesinin yüksek olduğunu göstermektedir. Böylece baklagillerin kurutularak veya saman haline getirilerek hayvanlara yedirilmesi yerine silaj yapılması, besleme değerinde olumlu sonuçlara neden olabileceği düşünülmektedir.

Ham Protein Oranı, Ham Protein Verimi, Silaj pH Değeri, Silaj Kuru Madde Oranı

Ham protein oran1, ham protein verimi, silaj $\mathrm{pH}$ değeri, silaj kuru madde oranı bakımından türler arasındaki farklılık istatistiki açıdan $\mathrm{p}<0.05$ düzeyinde; Laktik asit oranı bakımından ise $\mathrm{p}<0.01$ düzeyinde önemli bulunmuştur. En yüksek ham protein oranı aralarında istatistiki fark olmayan türlerden koca fĭğ, yem bezelyesi, mürdümük ve macar fiğinde belirlenirken; en yüksek ham protein verimi yem bezelyesi ve yem baklası hariç aralarında istatistiki farklılık bulunmayan diğer türlerden elde edilmiştir. Türlerin ham protein oranları sayısal olarak değerlendirildiğinde \%16.59-20.33, ham protein verimleri ise $55.87-178.66 \mathrm{~kg} / \mathrm{da}$ arasında değiştiği, ortalamaları ise sırasıyla $\% 18.32$ ve $132.97 \mathrm{~kg} / \mathrm{da}$ olarak gerçekleştiği Çizelge 6'da görülmektedir. Türlerden elde edilen silaj, pH değeri açısından incelendiğinde yem baklası ve tüylü fiğ hariç, diğer türler arasında istatistiki farklılık görülmemiştir. Ancak türlerin silaj $\mathrm{pH}$ değerleri 3.95-4.63 arasında değişmiş olup, en yüksek 4.63 ile macar fiği, en düşük ise 3.95 ile yem baklası türünden elde edilmiştir. Türlerin silaj $\mathrm{pH}$ değeri ortalaması ise 4.40 olarak tespit edilmiştir. Türlerin laktik asit oranları \%1.80-2.03 arasında değişmiş olup, \%2.03 ile en yüksek yem baklası, \%1.80 ile en düşük burçak türünden elde edilmiştir. Türlerin laktik asit oranı ortalaması ise \%1.89 olarak belirlenmiştir. Ayrıca macar fiği, koca fiğ ve yem baklası türleri hariç diğer türler arasında silaj kuru madde oranları bakımından istatistiki farklılık görülmemiştir. Türlerin silaj kuru madde oranları sayısal olarak değerlendirildiğinde \%30.76-37.27 arasında değiştiği, en yüksek \%37.27 ile tüylü fiğg en düşük ise \%30.76 ile yem baklası türünden elde edildiği ve ortalama silaj kuru madde oranı \%34.53 olarak gerçekleştiği Çizelge 6'da görülmektedir. Çalışmada elde edilen silaj kuru madde oranı ortalaması (\%34.53)'na göre; kaliteli bir silajda kuru madde oranının \%23.5 ve üzeri olması gerektiğini ifade eden Açıkgöz (1995)'ün bulgularıyla uyumlu olduğundan, elde edilen silajın bu bakımından kaliteli olduğu anlaşılmaktadır. 
Çizelge 6. İncelenen özelliklere ait ortalama değerler

\begin{tabular}{|c|c|c|c|c|c|}
\hline Türler & $\begin{array}{c}\text { Ham Protein } \\
\text { Oranı } \\
(\%) \\
\end{array}$ & $\begin{array}{c}\text { Ham Protein } \\
\text { Verimi } \\
(\mathrm{kg} / \mathrm{da}) \\
\end{array}$ & $\begin{array}{c}\text { Silaj pH } \\
\text { değeri }\end{array}$ & $\begin{array}{c}\text { Silaj kuru } \\
\text { madde oranı } \\
(\%)\end{array}$ & $\begin{array}{c}\text { Laktik asit } \\
\text { oranı } \\
(\%)\end{array}$ \\
\hline Koca fiğ (Görkem) & $20.33 \mathrm{a}$ & $126.41 \mathrm{ab}$ & $4.34 \mathrm{ab}$ & $32.32 \mathrm{~cd}$ & $1.88 \mathrm{~b}-\mathrm{d}$ \\
\hline Yem bezelyesi (Gap pembesi) & $18.98 \mathrm{ab}$ & $110.34 \mathrm{bc}$ & $4.34 \mathrm{ab}$ & $34.83 \mathrm{a}-\mathrm{c}$ & $1.90 \mathrm{bc}$ \\
\hline Çemen (Berkem) & $17.38 \mathrm{bc}$ & $168.77 \mathrm{ab}$ & $4.55 \mathrm{ab}$ & $36.50 \mathrm{ab}$ & $1.93 \mathrm{~b}$ \\
\hline Yem baklası (Göryaka) & $17.53 \mathrm{bc}$ & $55.87 \mathrm{c}$ & $3.95 \mathrm{c}$ & $30.76 \mathrm{~d}$ & $2.03 \mathrm{a}$ \\
\hline İskenderiye üçgülü (Derya) & $18.36 \mathrm{bc}$ & $161.64 \mathrm{ab}$ & $4.56 \mathrm{ab}$ & $34.50 \mathrm{a}-\mathrm{d}$ & $1.86 \mathrm{~b}$ \\
\hline Burçak (Hat-8) & $18.01 \mathrm{bc}$ & $178.66 \mathrm{a}$ & $4.44 \mathrm{ab}$ & $35.26 \mathrm{a}-\mathrm{c}$ & $1.80 \mathrm{~d}$ \\
\hline Mürdümük (Gap mavisi) & $18.96 \mathrm{ab}$ & $139.51 \mathrm{ab}$ & $4.37 \mathrm{ab}$ & $34.68 \mathrm{a}-\mathrm{c}$ & $1.86 \mathrm{~b}$ \\
\hline Macar fiği (Tarm beyazı) & $18.75 \mathrm{ab}$ & $158.70 \mathrm{ab}$ & $4.63 \mathrm{a}$ & $32.92 \mathrm{~b}-\mathrm{d}$ & $1.83 \mathrm{~cd}$ \\
\hline Tüylü fiğ (Efes 79) & $16.59 \mathrm{c}$ & $115.21 \mathrm{a}-\mathrm{c}$ & $4.23 \mathrm{bc}$ & $37.27 \mathrm{a}$ & $1.91 \mathrm{bc}$ \\
\hline Yaygın fiğ (Doruk) & $18.27 \mathrm{bc}$ & $114.61 \mathrm{a}-\mathrm{c}$ & $4.54 \mathrm{ab}$ & $36.26 \mathrm{ab}$ & $1.88 \mathrm{~b}-\mathrm{d}$ \\
\hline Ortalama & 18.32 & 132.97 & 4.40 & 34.53 & 1.89 \\
\hline LSD & $3.74 *$ & $136.84 *$ & $0.72 *$ & $8.02 *$ & $0.19 * *$ \\
\hline
\end{tabular}

":Ortalamalar arasındaki fark $(\mathrm{p}<0.05)$ düzeyinde önemli, ${ }^{* *}$ : Ortalamalar arasındaki fark $(\mathrm{p}<0.01)$ düzeyinde önemli

Baklagil yem bitkileri türlerinin ham protein oranları, ham protein verimi, silaj pH değeri, silaj kuru madde oranı, laktik asit oranı ile ilgili elde edilen bulgular; Kara (2015), Yücel ve ark. (2017), Kaplan (2013), Alp (2019), Seydoşoğlu (2019), Turan ve Sakman (2019), Turan (2019) ve Altınok (2001)'un tek yıllık bazı baklagil yem bitkilerinin tür, çeşit ve hatlarıyla yaptıkları çalışmalarda elde ettikleri bulgulardan düşük/yüksek veya uyumlu olduğu saptanmıştır. Türlerin ortalama ham protein oranları (\%18.32); baklagil, buğdaygil ve baklagil karışımlarına ait kalite standartlarına (Rohweder et al., 1978) göre değerlendirildiğinde 1. kalite sınıfinda yem elde edildiği görülmektedir (Çizelge 3). Gerek denemede yer alan baklagil yem bitkileri türleri ve gerekse diğer çalışma değerleri arasında belirlenen farklılıklar; çeşitlerin genotipik özellikleri ile çalışma yerlerinden ve ekolojik koşullardan kaynaklandığı ifade edilebilir. Nitekim Ball ve ark. (2001), kuru madde ve protein oranlarının çeşitler arasında farklı olması bitkinin genetik yapısından kaynaklandığı gibi ayrıca yaprak, başak ve gövde oranları, olgunlaşma dönemine, sicaklığa ve gübrelemeye göre değiştiğini ifade etmiştir. Başka araştırıcılar ise (Albrecht ve Beauchemin, 2003), çözülebilir protein oranı baklagil kuru otunda \%37.7 iken, silajında \%55.8; Davies (1991), besin maddesi ihtiyacı yüksek olan hayvanların beslenmesinde baklagil silajlarının üstünlüğü daha belirgin olarak görülmekte olduğunu ifade etmektedir. $\mathrm{Bu}$ nedenle buğdaygillere kıyasla baklagil yem bitkileri silaj olarak yedirildiğinde daha yüksek hayvansal verim sağlamaktadır (Hoffman ve ark., 1998). 


\section{SONUÇ ve ÖNERILER}

Elde edilen bulgular birlikte değerlendirildiğinde; bitki boyu, kuru ot oran1, NDF ve KMT parametrelerinde istatistiki farklılık görülmemiştir. Yeşil ot verimi bakımından iskenderiye üçgülü ve burçak; kuru ot verimi bakımından burçak, mürdümük ve tüylü fiğ; ADF ve silaj KM oranı açısından tüylü fiğg; SKM, NYD ve laktik asit oranı bakımından yem baklası; HP oranı bakımından koca fiğ, HP verimi bakımından burçak; silaj $\mathrm{pH}$ değeri açısından macar fiği öne çıkmıştır. Tüm özellikler göz önünde bulundurulduğunda; hem verim hem de kalite açısından Siirt ekolojik koşullarında ve benzer ekolojilerde burçak ve fiğ türleri diğer türlere göre daha üstün olduğu sonucuna varılmıştır.

\section{KAYNAKÇA}

Açıkgöz, E. 1995. Yem Bitkileri, Uludağ Üniversitesi Ziraat Fakültesi Yayınları. Bursa.

Açıkgöz, E. 2001. Yem Bitkileri. Uludağ Üniversitesi Ziraat Fakültesi Yayınları No: 42, Bursa.

Akbay, F., Erol, A. 2020. Farklı çemen genotiplerinin tarımsal ve morfolojik özellikler yönünden değerlendirilmesi. International Agricultural Congress of Muş Plain, 24-27 September 2019.
Albrecht, K.A., Beauchemin, K.A. 2003. Alfalfa and other perennial legumes silage, 1n silage science and technology. Agron, Monogr, 42, ASA, CSSA, and SSSA, Madison, WI, p, 633-664.

Alp, H. 2019. Şanlıurfa ekolojik koşullarında çemen (Trigonella foenumgraecum L.) bitkisinde farkl1 ekim zamanlarının tarımsal karakterlere etkisinin araştırılması. Yüksek Lisans Tezi, Harran Üniversitesi Fen Bilimleri Enstitüsü, Şanlıurfa, $28 \mathrm{~s}$.

Altınok, S. 2001. Tüylü fĭğ (Vicia villosa L.) ve koca fiğ (Vicia narbonensis L.)'in arpa (Hordeum vulgare L.) ile farkl1 oranlardaki karışımlarının silaj kalitesine etkileri. Tarım Bilimleri Dergisi, 8(3): 232237.

Anonim, 2001. Tarımsal Değerleri Ölçme Denemeleri Teknik Talimatı. “Serin İklim Tahılları', T.C. Tarım ve Köyişleri Bakanlığı Koruma ve Kontrol Genel Müdürlüğü Tohumluk Tescil ve Sertifikasyon Merkezi Müdürlüğü, Ankara.

Anonim, 2015. http://www.dunyagida.com.tr/haber.php?ni $\mathrm{d}=3222$ (Erişim Tarihi: 01.12.2019).

Bakoğlu, A., Kökten, K., Karadavut, U. 2004. Bazı macar fiği (Vicia pannonica C.) hat ve çeşitlerinin Bingöl kuru şartlarına 
adaptasyonu üzerine bir çalışma. III. Bingöl

Sempozyumu, Bingöl, 94-99.

Ball, D.M., Collins, M., Lacefield, G.D., Martin, N.P., Mertens, D.A., Olson, K.E., Putnam, D.H., Undersander, D.J., Wolf, M.W. 2001. Understanding Forage Quality. American Farm Bureau Federation Publication, 1-01, Park Ridge, IL.

Bernadette, J., Christian, H., Christian, E. 2000. Within and among cultivar genetic variation in alfalfa forage quality. Morphology and Yield. Crop Science. 40: 365-369.

Collins, M. 1983. Wetting and Maturity Effects on The Yield and Quality of Legume Hay. Crop Science, 75: 523-527.

Davies, O.D. 1991. The Value of Clover in Grass/Clover Silage When Fed to Dairy Cows. Anim. Prod. 52:589.

Hoffman, P.C., Combs, D.K., Casler, M.D. 1998. Performance Of Lactating Dairy Cows Fed Alfalfa Silage Or Perennial Ryegrass Silage. J. Dairy Sci. 81:162-168.

Hoy, M. D., Moore K. J., George, J. R., Brummetr, E. C. 2002. Alfalfa Yield and Quality as Influenced by Establishment Method. Agriculture Journal, 94: 65-71.

Kaplan, M. 2013. Yaygın fiğ (Vicia sativa $\mathrm{L}$.) genotiplerinde hasat zamanının ot verim ve kalitesine etkisi. Erciyes
Üniversitesi Fen Bilimleri Enstitüsü Dergisi, 29 (1): 76-80.

Kara, E. 2015. Aydın koşullarında kışlık ara ürün olarak yetiştirilecek tek yıllık bazı baklagil ve buğdaygil yem bitkilerinin verim ve kalite özelliklerinin belirlenmesi. Yüksek Lisans Tezi, Adnan Menderes Üniversitesi Fen Bilimleri Enstitüsü, Aydın.

Karslı, M.A., Akdeniz, H., Levendoğlu, T., Terzioğlu, Ö. 2005. Evaluation of the nutrient content and protein fractions of four different common vetch varieties. Turk J. Vet. Anim. Sci. 29:pp.1291-1297.

Kendir, H. 1999. Farklı kökenli burçak [Vicia ervilia (L.) Willd.] hatlarının tohum verimleri ve bazı bitkisel özellikleri. Tarım Bilimleri Dergisi, 5 (2): 110-117.

Kjos, N.P. 1990. Evaluation of the feeding value of fresh forages, silage and hay using near inhered reflectance analysis (NIR). LA Comparison Of Different Methods For Predicting The Nutritive Value. Norwegian J. Agric. Sci., 4: 305320.

Kökten, K., Bakoğlu, A. 2011. Elazı̆̆ koşullarında mürdümük (Lathyrus sativus L.)'te farklı sıra arasının tohum verimi ve verim öğeleri üzerine etkisi. Bingöl Üniversitesi Fen Bilimleri Dergisi, 1(1): 3742. 
Kökten, K., Boydak, E., Kaplan, M., Seydoşoğlu, S., Kavurmacı, Z. 2013. Bazı soya fasulyesi (Glycine $\max$ L.) çeşitlerinden yapılan silajların besin değerlerinin belirlenmesi. Türk Doğa ve Fen Dergisi, 2(2): 7-10.

Kökten, K., Kaplan, M., Seydoşoğlu, S., Yılmaz, H.Ş., Uçar, R. 2018. bingöl koşullarında bazı burçak [Vicia ervilia (L.) Willd] genotiplerinin ot verimi ve kalite özelliklerinin belirlenmesi. Türkiye Tarımsal Araştırmalar Dergisi, 5(3): 236245.

Kökten, K., Kaplan, M., Seydoşoğlu, S., Tutar, H., Özdemir, S. 2019. Bingöl koşullarında bazı burçak (Vicia ervilia (L.) Willd) genotiplerinin tohum verimi, kes verimi ve kes kalitesinin belirlenmesi. Ege Üniversitesi Ziraat Fakültesi Dergisi, 56 (1): 27-33.

Özdemir, B., Gürbüz, B. 1998. Seçilmiş bazı çemen (Trigonella foenum-graecum L.) hatlarının verim ve verim özellikleri üzerinde araştırmalar. Tarla Bitkileri Merkez Araştırma Enstitüsü Dergisi, (7): 2. Rohweder, D. A., Barnes, R. F., Jorgensen, N. 1978. Proposed Hay Grading Standards Based on Laboratory Analyses For Evaluating Quality. Journal of Animal Science, 47(3): 747759.
Seydoşoğlu, S., Sayar, M. S., Başbağ, M. 2013. Diyarbakır ekolojik koşullarında bazı koca fiğ genotiplerinin verim ve verim unsurları. Türk Tarım ve Doğa Bilimleri Dergisi, 1(1): 64-71.

Seydoşoğlu, S., Saruhan, V., Kökten, K. 2015. Diyarbakır ekolojik koşullarında bazı burçak (Vicia ervilia L. Willd) genotiplerinin verim ve verim unsurlarının belirlenmesi. Gaziosmanpaşa Üniversitesi Ziraat Fakültesi Dergisi, 32(2):107-115.

Seydoşoğlu, S. 2019. Farklı oranlarda karıştırılan yem bezelyesi (Pisum sativum L.) ve arpa (Hordeum vulgare L.) hâsıllarının silaj ve yem kalitesine etkisi. Ege Üniversitesi Ziraat Fakültesi Dergisi, 56(3): 297-302.

Stoilova, T., Pereira, M.G. 1999. Morphological characterization of 120 lentil (Lens culinaris Medic.) Accessions. Lens Newsletter, 1(2): 7-9

Taştan, V. 2016. Koca fï̆ (Vicia narbonensis L.) silajlarında farklı katk1 maddeleri kullanımının silaj fermantasyonu üzerine etkileri. Yüksek Lisans Tezi, Namık Kemal Üniversitesi Fen Bilimleri Enstitüsü, Tekirdağ, 47.

Turan, N. 2019. Macar fiği ile arpa yaş otunun farklı oranlarda karıştırılarak elde edilen silajın kimyasal kompozisyonu ve kalite parametrelerinin belirlenmesi. 
Avrupa Bilim ve Teknoloji Dergisi, 17: 787-793.

Turan, N., Sakman, H. 2019. Yarı kurak iklim koşullarında yazlık olarak yetiştirilen bazı koca fiğ (Vicia narbonensis L.) çeşitlerinin ot verimi ve kalitesinin belirlenmesi. Anadolu Tarım Bilimleri Dergisi, 34 (2019): 377-385.

Van Dyke, N.J., Anderson, P.M. 2000. Interpreting a Forage Analysis. Alabama Cooperative Extension Circular, ANR-890.
Yolcu, H., Tan, M. 2008. Ülkemiz yem bitkileri tarımına genel bir bakış. Tarım Bilimleri Dergisi, 14(3): 303-312.

Yücel, C., Avcı, M., İnal, İ., Akkaya, M. R. 2017. İskenderiye üçgülü (Trifolium alexandrinum L.) 1slah çalışmaları. Kahramanmaraş Sütçü İmam Üniversitesi Doğa Bilimleri Dergisi, 20 (özel sayı): 1721. 